NBER WORKING PAPER SERIES

TOWARDS A HISTORY OF THE JUNK BOND MARKET, 1910-1955

Peter F. Basile

Sung Won Kang

John Landon-Lane

Hugh Rockoff

Working Paper 21559

http://www.nber.org/papers/w21559

\author{
NATIONAL BUREAU OF ECONOMIC RESEARCH \\ 1050 Massachusetts Avenue \\ Cambridge, MA 02138 \\ September 2015
}

We thank the participants in a session at the Southern Economic Association Meetings in 2002, especially[Frank G. Steindl who organized the session, for many helpful comments. We also benefitted fromlpresentations to the workshop on the Development of the American Economy at the NBER summerlinstitute in July 2004 and to the Monetary and Financial History Workshop at the Federal Reserve Bank of Atlanta in May 2015. Elmus Wicker and Ellis Tallman provided thoughtful comments onla previous draft. Larry Officer generously shared his knowledge of interest rate series. Deepa Bhat provided able research assistance. The Sidney I. Simon Memorial Fund of Rutgers University provided financial assistance. We are responsible for the remaining errors. The views expressed herein are those of the authors and do not necessarily reflect the views of the National Bureau of Economic Research.

NBER working papers are circulated for discussion and comment purposes. They have not been peerreviewed or been subject to the review by the NBER Board of Directors that accompanies official NBER publications.

(C) 2015 by Peter F. Basile, Sung Won Kang, John Landon-Lane, and Hugh Rockoff. All rights reserved. Short sections of text, not to exceed two paragraphs, may be quoted without explicit permission provided that full credit, including $\odot$ notice, is given to the source. 
Towards a History of the Junk Bond Market, 1910-1955

Peter F. Basile, Sung Won Kang, John Landon-Lane, and Hugh Rockoff

NBER Working Paper No. 21559

September 2015

JEL No. N12

\begin{abstract}
$\underline{\text { ABSTRACT }}$
We present a new monthly index of the yield on junk (high yield) bonds from 1910-1955. We then use the index to reexamine some of the main debates about the financial history of the interwar years. A close look at junk bond yields: (1) strengthens the view that the decline in lending standards in the late 1920s was modest at best: (2) casts doubt on the view that the banking crisis that began in 1930 disrupted financial markets because banks liquidated their holdings of risky bonds; (3) strengthens the view that the cost of capital rose substantially in the early 1930s and remained high for the rest of the decade; (4) casts doubt on the view that financial markets entered a liquidity trap in the second half of the 1930s; and (5) strengthens the case for believing that junk bond yields contain some information useful for making economic forecasts.
\end{abstract}

Peter F. Basile

Department of Economics

Rutgers University

75 Hamilton Street

New Brunswick, NJ 08901

pbasile@att.com

Sung Won Kang

Korean Research Institute

8th FL., Hana Daetoo Securities Bldg., 27-3.

Yeouido-dong, Yeongdeungpo-gu

Seoul 150-705 Korea

sungwonk@keri.org
John Landon-Lane

Department of Economics

75 Hamilton Street

Rutgers University

College Avenue Campus

New Brunswick, NJ 08901-1248

lane@econ.rutgers.edu

Hugh Rockoff

Department of Economics

Rutgers University

75 Hamilton Street

New Brunswick, NJ 08901-1248

and NBER

rockoff@econ.rutgers.edu 


\section{Towards a History of the Junk Bond Market, 1910-1955}

\section{An Index of Junk Bond Yields, 1910-1955}

Interest rates play a major role in many controversies about the macroeconomic history of the United States during interwar years, including the classic controversy between the monetarists and the Keynesians over the role of money in the Great Depression. Within those controversies a number of economists - including among others Milton Friedman and Anna Schwartz (1963), Ben Bernanke (1983), Frederic Mishkin (1991), Charles Calomiris (1993), and Allan Meltzer (2003) - have drawn attention to the risk premium, the difference between the yield on a risky corporate bond and a safe corporate or government bond of similar maturity. These scholars have been forced to rely on the yield on Baa corporate bonds to measure risk because this is the lowest quality bond for which an index of yields has been calculated that covers most of the twentieth century. As indicated in table 1, however, Baa bonds are still relatively high on Moody's scale: Moody's described Baa bonds during the interwar years as "good quality." It may well be true that the Baa-Aaa spread is sufficient to tell us all we want to know: other risk spreads could be simple multiples of the Baa-Aaa spread. But to be sure that we have a full picture of the risk structure of the bond market we need information on lower rated bonds. Here we present a new monthly index of junk bond yields for the period 1910-1955 and with it revisit some of the controversies in which the behavior of the quality spread played a prominent role.

Junk bonds (or high yield bonds, to use a term more likely to encourage someone to buy one!) are bonds that have a high potential yield to maturity because of a high risk of default. A 
more formal definition makes use of the ratings assigned by Moody's, Standard and Poor's, or one of the smaller rating agencies. ${ }^{1}$ Typically today, junk bonds are defined as those that are rated Ba or below by Moody's and BB or below by Standard and Poor's. Here, however, we will restrict ourselves to bonds that were rated B or lower by Moody's, in order to focus on bonds that were clearly speculative. Peter F. Basile (1989) first computed the yields on a quarterly basis. Since then we have extended them to a monthly basis.

In constructing the index, we have followed the methodology developed by Frederic Macaulay (1938) in his classic study of interest rates. Although Macaulay's methods were developed long ago, there are several advantages in using him as a model. ${ }^{2}$ Many of the problems that Macaulay faced as he pushed his index back into the nineteenth century - a limited number of securities, missing prices, thin markets, and so on - are similar to the problems one encounters in computing an index of junk bond yields. More importantly, similar methods were used to compute the Aaa and Baa rates that most financial historians have relied on. By following Macaulay's methods we create an index which facilitates comparisons with their conclusions. The junk bond index and more detail on how it was constructed are presented in the appendix.

Most bonds, although by no means all, were rated Aaa or Baa when they were first issued. This is especially true for large Fortune-500 firms. So the junk bonds investigated here represent only a fraction of the total capitalization of the bond market. But it was by no means a trivial fraction. In the years from 1912 to 1944 examined by W. Braddock Hickman $(1958,150)$ bonds rated Ba or below on average made up about 24 percent of the book value of outstanding rated bonds. The peak was 1940 when bonds rated Ba or below accounted for 41.5 percent of the book value of outstanding rated bonds. Some of the bonds rated Ba or below were "fallen 
angels," bonds that had started out as highly rated bonds and been downgraded. But not all: some bonds were given low ratings when they were first issued.

Still, why should we look at them? Why not focus completely on the high-grade bonds? One reason for looking at junk bonds is that the firms that issue junk bonds are closer on the risk continuum to a large mass of firms that are too small and too weak to issue bonds at all, and that rely on banks or the informal capital market for funds A second reason for looking at junk bonds is that they may be a more sensitive indicator, perhaps a more sensitive leading indicator, of economic conditions than higher-grade bonds. The ratings on bonds can be compared with the grades we give our students. Most students (nowadays) receive A's, B's, and C's. And these are the students who are likely to go out into the world and make a name for themselves. But the D students should not be completely ignored.

Our monthly index of junk bond rates is plotted in figure 1, along with the Aaa and Baa rates. It is obvious that the Baa rate contains much of the information in the junk bond rate. The assumption that we can get a full picture of the risk structure by looking simply at the Baa-Aaa gap contains a grain of truth. But the junk bond rate is not a simulacrum of the Baa rate. Consider the following example. The Baa-Aaa gap peaked during the 1920-1921 contraction at about 351 basis points. This level was not surpassed until April 1931. The Junk Bond-Aaa spread, on the other hand, peaked at 643 basis points in February 1922, a level that was exceeded in April 1930, when the spread began a climb to unprecedented heights.

Perhaps the most important technical concern is whether the sample of junk bonds has to be changed frequently because of defaults, making the resulting index fundamentally different from indexes of the yields of safer assets. Those samples also need to be changed at regular intervals to maintain the maturity structure of the index, but it could be that the changes are less 
disruptive. Turnover in the junk bond index because of default, however, was surprisingly low during this period. This was one of Hickman's (1958) basic findings. Indeed, Michael Milken, the "Junk Bond King," relied on Hickman's finding to make his case for junk bonds. In addition, we addressed this concern by computing a simple average of all junk bond yields available at each point in time. The resulting series was quite similar to the chained index presented here, giving us additional confidence that the regular replacement of bonds in the index was not causing a problem. In short, we believe that the junk bond index is fully comparable to the widely used Aaa and Baa indexes.

Below we look at four controversies concerning the macroeconomics of the interwar years that we believe can be moved forward by studying the yield on junk bonds. We also look at the possibility of using the junk bond yield as a leading indicator. We begin with an important controversy about the behavior of capital markets in the late 1920s.

\section{Was There a Decline in Lending Standards the Late 1920s?}

In the wake of the Great Depression it was natural to ask whether the financial crisis had been intensified by the adoption of lax lending standards during the roaring twenties. Geoffrey Moore (1956), summarizing the literature, argued that the average quality of loans did indeed fall in the late 1920s. The main evidence was that default rates on loans made in the late twenties were higher than on loans made in the early twenties. It was hard, however, as Milton Friedman and Anna J. Schwartz (1963, 245-8) suggested in their critique of the literature, to separate a change in standards from bad timing. Consider two bonds: One is issued in 1925 and survives the 1930s; the other is issued in 1929 and is defaulted on in the early 1930s. It is tempting to conclude that bond issued in 1929 was riskier. But it may have been identical in every respect 
except date of issue to the bond issued in 1925. It may be simply that the firm that issued its bond in 1925 had a longer run of prosperous years in which to use the funds it raised, and strengthen itself against hard times. A child of 10, to use Friedman and Schwartz's analogy, may have a higher chance of surviving an epidemic than a child of 5, even though the children are otherwise similar.

There are, moreover, various ways of interpreting the notion of lax lending standards. The term might refer to a failure to make a sufficient effort to distinguish borrowers with a high probability of default from a low probability of default. Or it might mean an increased willingness to lend to a borrower known to be a high risk, a greater taste for risk. If lenders became lax in the latter sense in the late 1920s we would expect, other things equal, a decline in the yield on risky bonds.

Friedman and Schwartz (1963, p. 247, ftn. 7) appeal to this argument when they point to a decline in the risk premium in the late 1920s as evidence of an increase in the market's "taste for risk." The decline in the risk premium, however, was confined to the yield on Baa bonds, the riskiest class of bonds for which an index was available when Friedman and Schwartz wrote, which fell from 7.57 in 1920-1924 to 5.81 in 1925-1929. In 1928 and the first nine months of 1929 (before the crash) the yield on Baa's averaged 5.64. In the junk bond market, however, yields were more or less steady. Yields on junk bonds fell only slightly, from 10.55 to 10.35 , between 1920-24 and 1925-1929. And in 1928 and the first 9 months of 1929 the yield on junk bonds averaged 10.47, only a few basis points below the 1920-24 average.

To be sure, it appears that the supply of newly issued low-rated bonds increased in the late 1920s. According to Hickman $(1958,179)$ the proportion of newly issued bonds rated below Baa rose from $17.4 \%$ in $1920-24$ to $21.2 \%$ in $1925-29$. In $1928-29$ the proportion was $26.6 \%{ }^{3}$ So 
the stable junk bond yield means only that the increase in the market's taste for risk did not outrun the increase in the supply of risky bonds. Still, the evidence from the junk market strengthens the case for assigning a relatively modest role in the Great Depression to a possible decline in lending standards in the late 1920s. ${ }^{4}$

The issue of declining lending standards is closely related to the issue of whether there was a bubble in the stock market. As Peter Rappaport and Eugene White (1994) have shown, the cost of call loans rose dramatically with the stock market. This is evidence that while lending standards of investors in the stock market may have declined (or alternatively their estimates of future returns may have escalated), another segment of the capital market, the banks lending money to brokers, was highly skeptical. The decline in the price of junk bonds expands on this point. Even though some investors had become enthusiastic about the prospects of the stock market, such attitudes did not penetrate into the junk bond market. There, investors who wished to sell bonds in order to raise cash to invest in stocks had to offer high yields. Heterogeneous expectations are probably the norm, but perhaps differences were more pronounced in the late 1920s and early 1930s.

The behavior of junk bond rates in the late 1920s presents a sharp contrast with junk bond rates in the mid 1950s, a contrast that reinforces the view that lending standards remained relatively stable in the late 1920s. The prices of common stocks rose in both periods. But in the late 1920s the increase in stock prices was accompanied by stability in the price of junk bonds, while in the mid 1950s junk bond prices rose. During the three years from July 1926 to July 1929, to be more specific, stock prices rose 81.39 percent, while the yield on junk bonds rose 3.91 percent. During the comparable three years from October 1952 to October 1955 stock prices rose 55.15 percent, while the yield on junk bonds fell 7.60 percent. 
The difference between the periods appears to be that in the 1950s, unlike the 1920s, institutional investors - mutual funds, pension funds, and insurance companies - were willing to take on more risk and increase their holdings of junk bonds. Basile (1989, 143-146) provides evidence that all three institutional investors moved toward more risky portfolios. Of particular relevance here, Basile examined the portfolios of mutual funds reported in Investment Companies, a manual published by Arthur Wiesenberger, for listings of the bonds in his junk bond index. He found $(1989,146)$ that in 1948 large mutual funds held about \$16 million (at par value) in bonds in the junk bond index, and that by 1956 that number had risen to something between \$30.5 and \$48 million. Additional evidence shows that other institutional investors also were buying riskier assets in the 1950s.

In short, if we define lax lending standards as an increased willingness to lend to borrowers with obvious signs of risk, such as low bond ratings, then the evidence of the junk bond market reinforces the view that the decline in lending standards in debt markets (as opposed to equity markets) in the late 1920s was limited. A change in standards, however, may have taken place in the early 1950s.

\section{Did the First Banking Crisis Produce a Fire Sale of High-Risk Bonds?}

According to Friedman and Schwartz the first banking crisis in the Great Depression began in October 1930 and ended, or at least abated, in January 1931. Interest rates, they argued (1963, 312) showed the effects of the crisis because "a widening differential began to emerge between yields on lower-grade corporate bonds and on government bonds." They attributed the widening differential to decisions by banks and other holders to sell risky bonds while holding on to or buying governments. The resulting decline in the prices of low rated bonds in turn 
weakened the balance sheets of the banks and contributed to the subsequent collapse of the banking system. Friedman and Schwartz's point can be seen in Figure 2 which plots several bond yields, including the series they plotted. As you can see, the Baa rate starts to rise after the start of the first banking crisis consistent with Friedman and Schwartz's conclusion that banks began to sell risky bonds in order to accumulate reserves.

Peter Temin (1976, 103-121) challenged this analysis on both theoretical and empirical grounds in Did Monetary Forces Cause the Great Depression? Temin argued that the increase in the return on Baa bonds was produced by the increased risk of default or by an increased price of risk due to the worsening economic conditions, and not by a scramble for liquidity by the banks. Temin's argument is many sided, but one of Temin's main points concerns the timing of the movement in risky rates. Temin argued that the reason why the Baa rate remained relatively stable before the banking crisis was that the riskiest bonds in the sample were being downgraded and removed.

To test this theory, Temin created an index with a fixed group of bonds and followed it over the crucial years. Instead of finding a sharp jump correlated with the onset of the banking panic, Temin found a longer-term upward trend unaffected by the banking crisis. The yields on Temin's fixed sample are also plotted in figure 2. (Temin calculated yields at June and December dates, but we have connected those observations with straight lines to make the figure easier to read.) The fixed sample shows a much greater increase in rate of return than the Baa index. The increase, moreover, began before the first banking panic providing empirical evidence for Temin's contention. ${ }^{5}$

Our index of junk bond yields (also plotted in figure 2) throws additional light on this controversy. The yield on junk bonds began to rise in April 1930, before the yield on a similarly 
constructed index of Baa bonds, supporting the Temin's position. Why the inflexion should be in March and April 1930 is hard to say. But we believe that had our series been available to them Friedman and Schwartz would have modified their conclusion about the impact of the first banking panic. We have not been able to tie the inflexion to a particular event. It does look in this case, however, that the Junk Bond index was giving an early warning of the deluge to come. Elmus Wicker, in The Banking Panics of the Great Depression agreed with Temin that the first banking crisis did not produce a liquidity crunch because available interest rates, both short and long, did not rise significantly. In discussing long-term rates, Wicker (1996, p. 40) concluded that although there was an increase in Baa rates the bond market remained "calm and orderly." Overall, the thrust of Wicker's discussion, like Temin's, is that the banking difficulties in late 1930 made little impression on bond markets. But Wicker's portrait of a calm market applies to the lower risk securities. As far as the junk bond market was concerned something very bad was happening in 1930 .

Some quantitative evidence on how banks responded to the crisis is provided by Fred L. Garlock's (1941) neglected study of country banks in Wisconsin. Garlock went through reports by individual banks to the banking authorities, and for a select group he talked with bank managers and was given additional information. His study provides the most detailed picture that any of us is aware of, of the impact of the crash on security holdings. Obviously, it covers only rural banks in Wisconsin, and so is hardly a basis for generalization. Nevertheless, the results are suggestive. Table 2 shows the response in terms of their security portfolio of the banks in his special sample. As might be expected, all types of securities were liquidated in order to meet the rush of withdrawals. The surprising thing, however, is that the banks liquidated a larger proportion of their holdings of high grade bonds (line 3), and purchased more low grade 
securities. This evidence tells against the conjecture by Friedman and Schwartz that banks concentrated on selling lower rated bonds after the start of the banking crisis. It may be that during this initial phase of the Depression the banks hoped to maintain their earnings by liquidating their higher quality securities. It is also possible that higher rated bonds were easier to market quickly during the panics.

As the Depression wore on, however, the Wisconsin banks began to load up on safer securities. The effect of these changes can be seen in Table 3. The percentage of government bonds in bank bond portfolios declined from 1929 to 1932, and then rose dramatically between 1932 and 1935. The banks that survived without establishing a depositor's trust - that is without limiting access to deposits in any way - are shown in the second column by way of contrast. As might be expected, these banks were somewhat more conservative in 1929 than all banks, holding more of their bond portfolio in higher rated private securities (although not in governments) and less in lower rated and nonrated securities.

Although in Temin's view the banking crisis did not contribute to the decline in bond prices through a panic driven fire sale of bonds, the prior decline in bond prices, in his view did contribute to the banking crisis by reducing the value of bank assets. Eugene White (1984) followed up on Temin's conjecture and showed that while declines in bond prices did not seem to have been a factor in producing failures of National banks, it was a factor for state chartered banks.

The Vermont banks that White examined and the Wisconsin banks that Garlock examined obviously can do no more than form the basis for conjectures about how banks in urban areas and other regions of the country and how other financial intermediaries behaved. Information of the sort collected by Garlock for other financial intermediaries and for individuals 
would help identify where the selling pressure in the junk bond market was located. The response of particular individuals and institutions probably varied. Hickman (1958), for example, shows that the reclassification of bonds probably produced considerable selling pressure for certain institutions, although perhaps more in later banking crises than in the first crisis. Banks in some areas were often required to purchase only investment grade bonds, which were assessed at book value by bank examiners. Bonds rated below Baa were marked to market. When bonds were reclassified some banks, therefore, (Hickman 1958, p. 140) had a strong incentive to sell them to avoid substantial reported reductions in their capital values. Mutual Savings Banks, an important part of the banking system in the Northeast, moreover, could only invest in bonds that appeared on lists issued by state banking authorities. Typically, the bonds on the list were rated at Baa or above. When bonds were reclassified, banking authorities would remove them from the list of approved bonds, and the Mutual Savings Banks were forced to sell them promptly (Hickman 1958, p. 259). In short, while the Wisconsin country banks found it in their interest to dump governments and purchase lower rated securities, other intermediaries and individuals may have reacted differently, adding to the upward pressure on junk bond yields.

Irving Fisher (1930, 382-83), it is interesting to note, discussed divergent movements between high-risk and low-risk securities in the Theory of Interest. He concluded that it was possible in periods of great uncertainty for the rates on risky loans to rise and the rates on relatively safe loans to fall. Fisher cited the United States during the Civil War and Europe (but not the United States) during the First World War as times and places where great uncertainty had produced this divergence in interest rate movements. This seems to have been the case during the first banking crisis, although I do not know that Fisher had the conditions of 1930 in mind when he wrote about divergent movements in safe and risky asset. Later, as economic 
conditions worsened, and even strong corporations began to crumble, yields on highly rated corporates rose.

\section{Did the Cost of Credit Remain High throughout the 1930s?}

The well-known Bernanke (1983) thesis holds that the financial crisis of the early 1930s significantly increased borrowing costs for many firms and individuals. It is hard, however, to observe this process directly because it often took the form of credit rationing by financial intermediaries rather than increasing the rates charged to particular classes of borrowers. Measured bank lending rates, for example, increased to only a minor extent in the Great Contraction (Smiley 1981, Bodenhorn 1995). Bodenhorn divided the United States into four regions. In the North East the average bank lending rate fell 21 basis points between 1929 and 1932. In the South the lending rate rose 2 basis points; in the Plains states, 25; and in the West, 105. The reason why we do not see much change in bank lending rates may be that banks were focusing more of their lending on low-risk customers.

Bernanke (1983) relied on indirect evidence to make his point. He relied in part on evidence that the Depression worsened when bank failures increased. He also pointed to the spread between the Baa rate and the rate on long-term government bonds. But as Bernanke pointed out, the Baa rate is not entirely convincing as a proxy for the cost of credit intermediation because the Baa rate applies to large companies with relatively high credit ratings. Typically, firms that relied on bank loans for a significant portion of their capital were smaller and less well known. But our index of junk bond yields provides a measure of the cost of credit to firms closer to the type that Bernanke and others thought would be most affected by the banking crisis. In subsequent work on the bank-lending-channel Bernanke and others - for 
example, Bernanke, Gertler, and Gilchrist (1996) - have relied on comparisons of large and small firms, the latter presumably more sensitive to changes in the availability of credit. ${ }^{6}$

From 1925 to 1929 the difference between the Baa and the rate on government bonds averaged 224 basis points. ${ }^{7}$ Between 1935 and 1939 it averaged 266 basis points, a difference of 42, about a 17 percent increase. This calculation illustrates Bernanke's argument that borrowing costs remained elevated in the second half of the 1930s. A look at the junk bond rate reinforces his story. Between 1925 and 1929 the difference between the Junk bond rate and the government rate averaged 677 basis points, while between 1935 and 1939 it averaged 919, a difference of 242 basis points, a 31 percent increase in the premium. The junk bond rate, in other words, suggests that small, lesser known firms still faced substantial cost-of-capital problems in the second half of the 1930s, reinforcing Bernanke's claim to have developed a theory that can explain the persistence of the Depression.

In Lessons from the Great Depression Temin (1989, p. 54), argued that the rise in the cost of borrowing could not have contributed much to the decline in output because the decline in output was concentrated among large firms, and large firms continued to have access to capital. Temin is undoubtedly right that the cost of credit problem was concentrated among the smaller and lesser known firms. Indeed, the rate on triple-A bonds, actually fell by 18 basis points between April 1930 and January 1931, while, as we noted above, the rates on junk bonds was rising. Hickman $(1958,183)$, moreover, showed that the percentage of large offerings which he defined as offerings over $\$ 5$ million - that were rated Ba or lower declined from 23.8 percent in 1929 (to be sure, an unusually high year) to 12.2 percent in 1930 (a more normal year) to 8.9 percent in 1931 (unusually low), suggesting that it was the smaller firms that were being discouraged from issuing bonds. The locus of the investment decline, however, may differ from 
the locus of the output decline. Consider a small trucking firm that decides not to replace its old trucks because its cost of capital is high. It is the smaller firm that decreases its planned investment, but the larger firm, the automobile company, which decreases its output.

\section{Was There a Liquidity Trap in the 1930s? ${ }^{8}$}

Whether the U.S. entered a liquidity trap in the latter half of the 1930s has been a hardy perennial. Paul Krugman (1998) famously drew attention to what he regarded as the liquidity trap in the late 1930s when he argued that low interest rates in Japan (measured by the return on government bonds) during Japan's "lost decade” proved that monetary policy in Japan had become ineffective. The liquidity trap was "baaack."

The idea of a liquidity trap was developed by John Maynard Keynes who termed it "absolute liquidity preference" in the General Theory. Keynes argued that the demand for money could become almost perfectly elastic with respect to the rate of interest, especially at very low interest rates. Absolute liquidity preference derived from the role played by speculators in bond markets; a role that Keynes, himself a speculator, knew well. If speculators agreed that the current interest rate was "normal" then any attempt by the central bank to lower rates by buying bonds would be counterbalanced by the willingness of speculators to sell bonds; and any attempt to raise rates would be counterbalanced by the willingness of speculators to buy bonds. A liquidity trap would be more likely as rates approached zero. Speculators would then be almost certain that if rates moved substantially in any direction, it would be up. If the central bank attempted to lower rates still further, speculators would be more than willing to exchange bonds that paid little for cash while they waited for a fall in bond prices. The implication of the liquidity trap was that monetary policy would be powerless to affect interest rates, and therefore 
powerless to affect investment spending and the remainder of the economy. In Keynes's view, only fiscal policy or radical controls over private investment could then stimulate the economy.

While most economists know that Keynes is the creator of the liquidity trap, few remember that in the General Theory he (1965 [1936], 207) suggested that while it was an important theoretical possibility it had not yet arisen in the real world.

There is the possibility, for reasons discussed above, that, after the rate of interest has fallen to a certain level, liquidity-preference may become virtually absolute in the sense that almost everyone prefers cash to holding a debt which yields so low a rate of interest. In this event the monetary authority would have lost effective control over the rate of interest. But whilst this limiting case might become practically important in the future, I know of no example of it hitherto. Indeed, owing to the unwillingness of most monetary authorities to deal boldly in debts of long term, there has not been much opportunity for a test.

How central this qualification was in Keynes's thinking is debatable. For one thing, the General Theory, was written before Keynes could observe the late 1930s (the preface was dated December 13, 1935) when the rate on short-term federal government debt in the United States was stuck near zero. More directly relevant to our concerns, Keynes also pointed out that even though risk free rates might be brought to very low levels by central bank monetary policies, rates on risky assets might remain at unacceptably high levels.

Thus the rate of interest that the typical borrower has to pay may decline more slowly than the pure rate of interest, and may be incapable of being brought, by the methods of the existing banking and financial organization, below a certain minimum figure (Keynes 1965 [1936], 208).

Although Keynes was cautious about the existence of a liquidity trap, his American followers had no doubt that the United States had entered a liquidity trap in the second half of the 1930s. Alvin Hansen $(1953,132)$, often described as the man who brought Keynesian economics to America, thought Keynes's qualifications "strange and inconsistent." In Hansen's view it was 
clear that "In fact, the United States during the thirties (especially from 1934 on) was a good example [of a liquidity trap]." 9

A substantial literature followed attempting to establish or refute existence of a liquidity trap in the 1930s. Much of the earlier literature is cited in Karl Brunner and Allan Meltzer's (1968) attack on the notion of a liquidity trap. More recently Christopher Hanes (2006, 2014) showed that during the 1930s changes in bank reserves and changes in Federal Reserve asset purchases influenced long-term government bond rates, even though overnight rates were close to zero.

A central point of Brunner and Meltzer, one that points directly to the need for an index of junk bond yields, was that it is not enough to look simply at rates on government bonds: One must look at the whole range of securities. Milton Friedman $(1971,28)$ took a similar position. Friedman argued that the difference between monetarists and Keynesians was "was less in the nature of the process than in the range of assets considered," and that he and fellow monetarists regarded "the market rates stressed by the Keynesians as only a small part of the spectrum of rates that are relevant." Indeed, Friedman would have gone so far as to include "durable and semi-durable consumer goods, structures, and other real property" in the list of asset prices affected by changes in the stock of money, creating a direct link between money and real economic activity. ${ }^{10}$

Many economists, we believe, reject the idea that monetary policy could influence highrisk securities without first influencing yields on government bonds to an even greater extent. ${ }^{11}$ They rely on what Temin (1976, 96-103) calls the "pebble in the pond" theory of the transmission of monetary shocks. A pebble thrown into a pond produces a wave of large amplitude where it hits the water, a wave which diminishes as it approaches the shore. In the 
same way, an increase in the stock of money would have a large impact on the market for assets that are closest to money, short-term-low-risk bonds such as treasury bills, but would have a diminishing impact as one moved further away -- toward low-risk corporate bonds, high-risk corporates, stocks, and so on.

This sequence makes the most sense, it seems to us, when the change in the stock of money is generated by open market operations, when the stone is in fact thrown in the center of the pond. It is one of the unique features of the 1930s that some of the major changes in the stock of money were brought about by changes in the reserve ratios of banks, and by changes in the currency-deposit ratios of the public. Given one of these starting points, it is less obvious that government bond rates would show the first and largest effects.

It is possible to imagine, moreover, adjustment paths in which monetary shocks made a smaller impression on assets similar to money and a larger impression on less similar assets. We call this the "tsunami in the sea" theory of the transmission of monetary shocks to contrast it with the "pebble in the pond" theory. ${ }^{12}$ Suppose wealth holders view assets as lying on a money continuum with cash having the highest degree of "moneyness," deposits having the next highest, short-term government bonds the next highest, and so on. And suppose that the perceived moneyness of deposits declines as a result of the rising tide of bank failures. What would be the most direct way to restore the initial level of total liquidity? Rather than sell, say, $\$ 100$ of government bonds (a near money) to acquire $\$ 100$ of cash, a transaction that would have little impact on the overall liquidity position of the wealth holder, it might have been more effective to sell, say, $\$ 100$ of junk bonds and acquire $\$ 100$ in government bonds or cash.

Since the possibility of a liquidity trap in the 1930s is still unresolved and relevant to current problems, we undertook our own exploration using our index of junk bond returns. 
Figure 3 shows the rate of growth of M2, the yield on Aaa corporate bonds, the yield on Baa Bonds, and the yield on junk bonds, from January 1935 to December $1941 .{ }^{13}$ Money growth, which is normally positive, turned negative on an annual in November 1937. The rate on Aaa bonds hardly moves. If one were to look only at the Aaa rate (or the government bond rates where the effect is even smaller) one would conclude that the United States was in a liquidity trap. If one looks at the rate on Baa bonds, however, one does see, as Meltzer (2003, 519-20) points out, an increase in rates. And if one looks at the yield on junk bonds, one sees a dramatic rise. The data in short, is consistent with the continued effectiveness of monetary policy. ${ }^{14}$

This evidence, although it strengthens the case against the liquidity trap, is unlikely to end debate. For one thing, the liquidity trap is an asymmetric concept. The liquidity preference curve, as we usually imagine it, is a relationship between the rate of interest measured on the vertical axis and the amount of money measured on the horizontal axis that slopes downward to the right over some normal range, but flattens out in a liquidity trap as the rate nears zero. If the economy is near the point at which the curve flattens out, decreases in the stock of money will raise rates, but increases will not lower them. There is, moreover, an alternative explanation for the rise in the yields on Baa and junk bonds shown in Figure 3: the recession that ran from May 1937 to June 1938, according to the NBER chronology. Investors were afraid that 1929-1933 had returned, and the perceived probability of defaults rose. It is conceivable, therefore, that nonmonetary forces produced the recession, which in turn produced the increases in Baa and junk bond yields, and that the decline in the stock of money was produced by independent shocks, the famous doubling of bank reserve ratios and sterilization of gold inflows stressed by Friedman and Schwartz. 
To push the analysis further we estimated a simple vector auto regression that includes, in the order in which they were entered, an indicator of general economic conditions, money (M2), and the yield on junk bonds. The number of observations in the liquidity-trap period, of course, is relatively small so any conclusions will be tentative. If we define the period of the alleged liquidity trap as running, say, from the resolution of the banking crises to U.S. entry into World War II -- from the first quarter of 1934 to the fourth quarter of 1941 -- we have only 128 monthly observations.

To begin with we estimated a VAR with lagged values of the rate of growth of Department Store Sales to capture general economic conditions. We started with two lags and added more based on statistical significance. In the charts included here we used 12 lagged values of each variable. The equation was estimated in first differences because testing showed that the possibility of unit roots in the underlying series could not be rejected.

The resulting impulse-response chart for the response of changes in the junk bond yield to innovations in the growth of M2 is shown in figure 4. The picture is consistent with the hypothesis that monetary policy had an impact on the junk bond yield that was independent of influences running from the general level of economic activity. The effect is negative, but deteriorates after a number of months, as might be expected from a liquidity effect. The wide two-standard deviation boundaries in the figure, however, warn that we cannot rule out the possibility of no liquidity effect at conventional probabilities. Figure 5 shows the patterns for government bonds, Baa bonds, and Junk bonds. Again one can see the negative impact of increases in liquidity on yields. One can also see the "tsunami in the sea" effect: Aaa and Baa rates (the rates on assets closest to money) barely move in response to an increase in stock of money, while the impact on junk bond rates is substantial. 
We tested the robustness of the relationships shown in these figures in various ways.

(1) We estimated the relationship in levels. Here the results were less easy to interpret, although there was a negative impact on the junk bond rate from money growth. (2) We varied the order in which the variables were entered. This did not seem to make much difference to the resulting impulse-response functions as far as the response of junk bonds to money was concerned. (3) As indicated above, we settled on a large number of monthly lags by starting with two lags and then looking at the statistical significance of additional lags. When only a few lags were used the results did not show as clear a pattern as figures 4 and 5 . But the impulse-response charts were consistent with a negative liquidity effect in the junk bond market. (4) We tested the relationship during the period 1910 to 1933. Finding a relationship between monetary policy and junk bond yields during the earlier period would not provide much evidence against the view that there was a liquidity trap in the latter period. But finding no relationship would cast some doubt on any finding of a relationship within the period at issue. Again, we found a negative liquidity effect running from money to the yield on junk bonds, although there was an initial positive effect and the liquidity effect did not disappear; counterintuitive results. The failure of junk bond yields to return to normal after their increase in 1929 to 1933 may explain this result. (5) We tried indexes of industrial production rather than department store sales to measure general economic conditions. Again, the effect of money on the junk bond yield was strongly negative during liquidity trap era, but perversely, not during the period prior to the liquidity trap. (6) We estimated similar VARs using quarterly data so that we could use GNP to measure general market conditions. Here we used only 2 lagged values. A typical impulse-response figure for the impact of changes in the stock of money on changes in the junk bond yield is shown in figure 6 . Again, we see the expected liquidity effect. 
An alternative approach to analyzing the effects of monetary policy on junk bond yields in the Depression was undertaken by one of us, John Landon-Lane (2015). Rather than using regression techniques, Landon-Lane conducted an event study. His procedure was to look for narrow windows of time in which government purchases or sales of securities produced major changes in the stock of outstanding government debt (five percent or more by value), and then to look at the corresponding change in bond yields during those periods. This procedure addresses several possible problems with the VAR estimates. By looking at changes in the stock of outstanding bonds Landon-Lane avoids possible problems arising from the endogeneity of the stock of money. And by looking at narrow windows Landon-Lane minimizes the danger that changes in variables omitted from the regressions were producing the results that we attributed to monetary policy. Landon-Lane's study, however, confirmed the VAR results: large scale open market operations were accompanied by large changes in junk bond yields.

In the end we were persuaded that the evidence is consistent with the idea that changes in money led changes in the Baa and junk bond yields, and that the effects were large enough to be taken seriously. Our exploration of junk bond yields, in short, strengthens the case made by Brunner and Meltzer, Meltzer, and Hanes that monetary policy continued to have an impact on financial markets even as short-term government rates approached zero.

\section{Were Junk Bonds a Leading Indicator?}

The attempt to find leading indicators or other means of predicting the course of economic activity has proved a fraught enterprise for economists. Nevertheless, the suggestion is often made in the business press that junk bond yields are a good leading indicator of the stock

market or even of the economy as a whole. ${ }^{15}$ And econometric studies by Gertler and Lown 
(1999) and Mody and Taylor (2003) using recent data confirm that junk bond yields contain predictive information. Space does not permit a full exploration of this issue for the interwar years. We did, however, perform some suggestive preliminary calculations.

Table 4 shows the NBER cyclical turning points during the years covered by our index and the changes in the junk bond and the Baa premiums (the difference between the risky rate and the triple A rate) in the preceding three months. The upper panel shows the cyclical peaks and the lower panel, the troughs. Risk premiums would be expected to rise before a cyclical peak if investors anticipated the coming economic contraction and an increase in defaults. And this is what we see, for the upper turning points. The junk bond premium rose immediately prior to the peak in 8 of 10 cases, and the Baa premium did so in 6 of 10 cases. Perhaps the turning point of most interest is the peak in August 1929, the start of the Great Depression. The increase in the three months ending in July was 47 basis points, the third highest in the table. And there were substantial increases in the three months ending in June, 117 basis points, and the three months ending in May, 124 basis points. But while these were substantial increases, they were not unprecedented. There was a similar increase in junk bond yields in the months prior to the peak in May 1923, and also during the contraction that ran from May 1923 to July 1924.

The results for the cyclical troughs, however, were disappointing. The junk bond premium fell in only 3 of 10 cases prior to a trough. The Baa premium actually did better than the junk bond premium as a predictor of troughs; falling in 7 of 10 cases. All in all, this experiment suggests that while the risk premiums appear to have some predictive power, at keast when it comes to picking out peaks in the business cycle, teasing out robust results would not be easy. 


\section{The Importance of High Risk Securities}

Financial historians have long been interested in the returns on risky bonds. But they have hoped that looking at the first step on the risk ladder, the difference between Aaa and the government bond rate, or the second step, the difference between the Baa rate and the Aaa rate, would provide sufficient information. In this paper we present a new index of the yield on junk bonds (high risk bonds) during the tumultuous years from 1910 to 1955. As it turns out, the assumption that the Baa-Aaa gap contains considerable information about the performance of risky bonds in general has more than a grain of truth. But the junk bond rate is not just a simulacrum of the Baa rate. An examination of junk bond yield, we believe, move forward several key debates in American monetary history.

(1) One is the debate over whether lending standards declined in the late 1920s. Our index of junk bonds strengthens the case for believing that lending standards did not decline very much, at least for domestic securities, because yields on junk bonds remained stable in the late 1920s. The late 1920s may be contrasted, in this respect, with the early 1950s when junk bond yields declined in part because institutions that had previously been unwilling to buy them began to do so; in other words, because of a change in lending standards.

(2) An examination of our index of junk bond yields strengthens the argument that risk premiums began to rise before the first banking crisis which began in October 1930. This suggests that rising risk premiums were not the result of panic induced sales of junk bonds by banks. More information on which institutions held junk bonds and if and when they sold them would be a useful supplement to the junk bond yield index. A somewhat neglected study by Garlock (1941) of country banks in Wisconsin showed that in the initial slump the banks in his

sample actually sold a higher proportion of their high quality bonds. Only later did they begin 
shifting their bond portfolios toward the high quality end of the risk continuum by investing heavily in government bonds.

(3) An examination of our index of junk bond yields also strengthens the case for believing that borrowing costs rose substantially during the early 1930s and remained elevated for the remainder of the Depression decade. Bank lending rates as developed by Bodenhorn (1995) and Smiley (1981) do not show much of an increase, but this may be because of credit rationing by banks. Bernanke in his seminal (1983) paper pointed to the increase in the Baa rate as evidence that costs of credit intermediation rose substantially. Our junk bond index, which probably represents firms that were closer on the risk continuum to those that would borrow from banks, rose to extraordinary heights during the early 1930s. The junk bond rate began to come down as the economy recovered. But because of another sharp increase in the second half of the 1930s, the junk bond rate remained high for the remainder of the 1930s, consistent with Bernanke's idea that high borrowing costs help explain the duration of the Depression.

(4) The argument that the economy fell into a liquidity trap in the late 1930s appears more problematic after one looks at our index of junk bond yields. While government bond yields show virtually no response to the decline in the stock of money between 1937 and 1938, the yields on Baa bonds, and especially on junk Bonds, rose dramatically. Vector Auto Regressions reinforce the idea that there may have been a line of causation running from the changes in the stock of money to changes in the yields of risky assets. Recent work by LandonLane (2015) who carried out an events study of open market operations in the 1930s provides additional evidence that monetary policy remained effective. It is difficult, however, to draw incontestable conclusions because the number of observations is limited and much was happening. 
(5) A look at the junk bond index also strengthens the case for believing that junk bond yields have some information of value for forecasting economic conditions. In our period, however, the index appears to have been better at predicting contractions than expansions.

Our examination of the junk bond index also convinced us that it would be worthwhile extending the index forward and backward in time. By extending it forward in time we will be able to explore the effects of institutional changes (the Milken revolution for example) in the junk bond market. Extending the index backward in time, it must be admitted, will be a somewhat artificial exercise because it will mean extending the index into a period before formal rating systems existed. But we believe that an increased understanding of the price of high risk capital during a period of rapid economic growth and technological change would justify the effort, and we hope to accomplish these tasks in the future. 


\section{Endnotes}

1. Richard Sylla (2002) describes the history of the rating agencies. Moody's published the first ratings in 1909. This date determines the beginning of our series.

2. Macaulay (1938, Table 3) compiled monthly yields on a (changing) sample of railroad bonds from 1857 through 1936. Railroads, typically, were relatively safe investments. The yields on the worst bonds in his sample - we looked at the highest yielding bond and an average of the 5 highest yielding bonds - yielded less than the average for Moody's Baa bonds when both were available. Thus, his data cannot be used as a substitute for an index of junk bonds. In general the time series properties of the risky bonds in his sample are similar to those of the Baa bonds. The yield on Macaulay's 5 worst bonds peaks in May and June of 1932 and in April of 1933 as does the Baa series.

3. The agencies rated over 90 percent of the par amount of new issues.

4.The evidence for a decline in lending standards is more compelling for sovereign foreign debt (Mintz 1951).

5. Friedman and Schwartz $(1963,308)$ date the onset of first banking crisis as October 1930. They are less precise about the end of the crisis, but would seem to date it after the first of the year 1931. Temin $(1976,79)$ designates November and December 1930 as the first banking crisis. To some extent the dating depends on the variables one looks at. Friedman and Schwartz focus on the aggregate deposit-currency and deposit-reserve ratios.

6. Hunter (1982) also showed that large and small firms were affected differently by the Depression.

7. The yield of government bonds was from Historical Statistics (2006, series Cb57).

8. This section is based on Basile, Landon-Lane and Rockoff (2011) and Landon-Lane (2015)

9. A search of the economics literature on JSTOR revealed relatively few uses of the term "liquidity trap" in the years immediately following publication of The General Theory. The first references are in reviews of D.H.Robertson's Essays in Monetary Theory (1940) by Arthur W. Marget (1941), and J.R. Hicks (1942). So Robertson, who used the term to refer to Keynes's absolute liquidity preference, may deserve credit for the term. The first reference in an article is in a critical review of Keynes's contributions by Gottfried Haberler (1946).

10. Friedman stressed the range of assets again in "Comments on the Critics" $(1972,909-910)$

11. Mishkin (2001) describes several assets (stocks, housing values, and foreign exchange) through which monetary policy would influence the economy. But in each case the assumption 
appears to be that monetary policy would first influence "interest rates" and then asset prices and then the economy as a whole.

12. An earthquake or undersea volcanic eruption (a better analogy for the Great Depression?) behaves differently than a pebble in a pond. Sometimes the result is a tsunami; a wave that is barely noticeable on the surface when it is passing through deep water, but becomes compacted and grows in height as it enters the shallow water near the shore the wave, and can come ashore doing enormous damage.

13. The rate of growth of money plotted in the chart is the difference between the natural logarithm of M2 in a particular month and the natural logarithm of M2 twelve months earlier multiplied by 100 .

14. Garman and Fridson (1998) show that monetary factors influence junk bond yield spreads in recent years.

15. As this is written, August 25, 2015, the stock market is experiencing a severe downturn. Several weeks previously analysts were warning of a correction because rates were rising in the junk bond market. On the tenth, one prominent analyst, David Rosenberg, was quoted as saying that the junk bond market was "having a coronary." http://www.cnbc.com/2015/08/13/thejunkbond-market-is-having-a-coronary-david-rosenberg.html, accessed August 25, 2015. 


\section{References}

Basile, Peter F. "The Cyclical Variation of Junk Bond Risk Premiums in a Historical Perspective, 1910-1955," Masters Thesis, Rutgers University, 1989.

Basile, Peter F., John Landon-Lane, and Hugh Rockoff. 2011. "Money and Interest Rates in the United States during the Great Depression". In Monetary and Banking History: Essays in Honour of Forrest Capie, Eds. Geoffrey Wood, Terence Mills, Nicholas Crafts. London: Routledge, 2011, Chapter 7.

Bernanke, Ben S. "Nonmonetary Effects of the Financial Crisis in the Propagation of the Great Depression." The American Economic Review. 73 (1983): 257-276.

Bernanke, Ben, Mark Gertler, and Simon Gilchrist. "The Financial Accelerator and the Flight to Quality." The Review of Economics and Statistics. 78 (1996): 1-15.

Bodenhorn, Howard. 1995. "A More Perfect Union: Regional Interest Rates in the United States, 1880-1960." In Michael D. Bordo and Richard Sylla, eds. Anglo-American Financial Systems: Institutions and Markets in the Twentieth Century. New York: Irwin Professional Publishing, New York University Solomon Center.

Brunner, Karl and Allan H. Meltzer. "Liquidity Traps for Money, Bank Credit, and Interest Rates." The Journal of Political Economy. 76 (Jan. - Feb., 1968): 1-37.

Calomiris, Charles W. "Financial Factors in the Great Depression." The Journal of Economic Perspectives. 7, (Spring 1993): 61-85.

Friedman, Milton. "A Theoretical Framework for Monetary Analysis." NBER Occasional Paper 112. New York: National Bureau of Economic Research, 1971.

. "Comments on the Critics.” The Journal of Political Economy 80, (1972): 906-950.

Friedman, Milton and Anna J. Schwartz. A Monetary History of the United States, 1867-1960. Princeton: Princeton University Press, for the NBER, 1963.

"Money and Business Cycles." The Review of Economics and Statistics, Vol. 45, No. 1, Part 2, Supplement. (Feb., 1963), pp. 32-64.

. Monetary Statistics of the United States: Estimates, Sources, Methods. New York: Columbia University Press, for the NBER, 1970.

Garlock, Fred L. "Country Banking in Wisconsin during the Depression." U.S. Department of Agriculture: Technical Bulleting No. 777, July 1941.

Garman, M. Christopher and Martin S. Fridson. "Monetary Influences on the High Yield Spread versus Treasuries." In High-Yield Bonds: Market Structure, Portfolio Management, and 
Credit Risk Modelling, eds. Theodore M. Barhnhill, Jr., William F. Maxwell, and Mark R. Shenkman. New York: McGraw-Hill, 1998, pp. 251-68.

Gertler, Mark and Cara S. Lown. "The Information in the High Yield Bond Spread for the Business Cycle: Evidence and Some Implications." Oxford Review of Economic Policy, vol. 15, Financial Instability (Autumn 1999): 132-150.

Haberler, Gottfried. "The Place of the General Theory of Employment, Interest, and Money in the History of Economic Thought (in Keynes' Contributions to Economics: Four Views)." The Review of Economic Statistics. 28 (1946): 187-194.

Hanes, Christopher. The Liquidity Trap and U.S. Interest Rates in the 1930s. Journal of Money, Credit and Banking 38, (1) (Feb. 2006): 163-94.

. "Quantitative Easing in the 1930s." Mimeo, June 2014. Available at http://bingweb.binghamton.edu/ chanes/research/qein1930s.pdf, accessed August 2015.

Hansen, Alvin H. A Guide to Keynes. New York: McGraw-Hill Book Company, Inc., 1953.

Hickman, W. Braddock. Corporate Bond Quality and Investor Experience. Princeton: Princeton University Press, 1958.

Hicks, J.R. "The Monetary Theory of D. H. Robertson.” Economica, New Series 9 (Feb. 1942): 53-57.

Historical Statistics of the United States Millennial Edition Online. 2006. Retrieved from http://hsus.cambridge.org/.

Hunter, Helen Manning. "The Role of Business Liquidity during the Great Depression and Afterwards: Differences between Large and Small Firms." The Journal of Economic History 42 (1982): 883-902.

Keynes, John Maynard. 1965 [1936]. The General Theory Of Employment, Interest, and Money. New York: Harcourt, Brace \& World, Inc.

Krugman, Paul R. "It's Baaack: Japan's Slump and the Return of the Liquidity Trap.” Brookings Papers on Economic Activity. (1998): 137-87.

Landon-Lane, John. "Would Large Scale Asset Purchases have Helped in the 1930s: an Investigation of the Responsiveness of Bond Yields from the 1930s to Changes in Debt Levels." In Current Federal Reserve Policy under the Lessons of Economic History, ed. Owen F. Humpage, 241-386. Cambridge: Cambridge University Press, 2015.

Macaulay, Frederick R. The Movements of Interest Rates, Bond Yields and Stock Prices in the United States since 1856. New York: NBER, 1938. 
Marget, Arthur W. "Review of Essays in Monetary Theory by D. H. Robertson." The Review of Economic Statistics. 23 (1941): 147-151.

Meltzer, Allan H. A History of the Federal Reserve. vol. 1: 1913-1951. Chicago: University of Chicago Press, 2003.

Mintz, Ilse. Deterioration in the Quality of Foreign Bonds Issued in the United States 19201930. New York, NBER, 1951.

Mishkin, Frederic S. "Asymmetric Information and Financial Crises: A Historical Perspective." In Financial markets and financial crises. Hubbard, R. Glenn, ed., a National Bureau of Economic Research Project Report. Chicago and London: University of Chicago Press, 1991, Pp. 69-108.

. "The Transmission Mechanism and the Role of Asset Prices in Monetary Policy." NBER Working Paper, 8617, December 2001.

Mody, Ashoka and Mark P. Taylor. "The High-Yield Spread as a Predictor of Real Economic Activity: Evidence of a Financial Accelerator for the United States." IMF Staff Papers Vol. 50, No. 3 (2003): 373-402.

Moore, Geoffrey H. "The Quality of Credit in Booms and Depressions." The Journal of Finance, Vol. 11, No. 2. (May, 1956): 288-300.

Rappoport, Peter and Eugene N. White. "Was the Crash of 1929 Expected?" The American Economic Review, Vol. 84, No. 1. (Mar., 1994): 271-281.

Robertson, D. H. Essays in Monetary Theory. London: P.S. King and Son, Ltd., 1940.

Smiley, Gene. 1981. "Regional Variation in Bank Loan Rates in the Interwar Years." The Journal of Economic History, Vol. 41, No. 4. (Dec.): 889-901.

Sylla, Richard. "A Historical Primer on the Business of Credit Ratings." In Ratings, Rating Agencies and the Global Financial System, edited by Richard M. Levich, Giovanni Majnoni, Carmen M. Reinhart. Boston: Kluwer Academic Publishers, 2002.

Temin, Peter. Did Monetary Forces Cause the Great Depression? New York: W.W. Norton, 1976.

. Lessons from the Great Depression. Cambridge, Massachusetts: MIT Press, 1989.

White, Eugene Nelson. "A Reinterpretation of the Banking Crisis of 1930." The Journal of Economic History, 44 (1984): 119-138.

Wicker, Elmus. The Banking Panics of the Great Depression. Cambridge, New York: Cambridge University Press, 1996. 


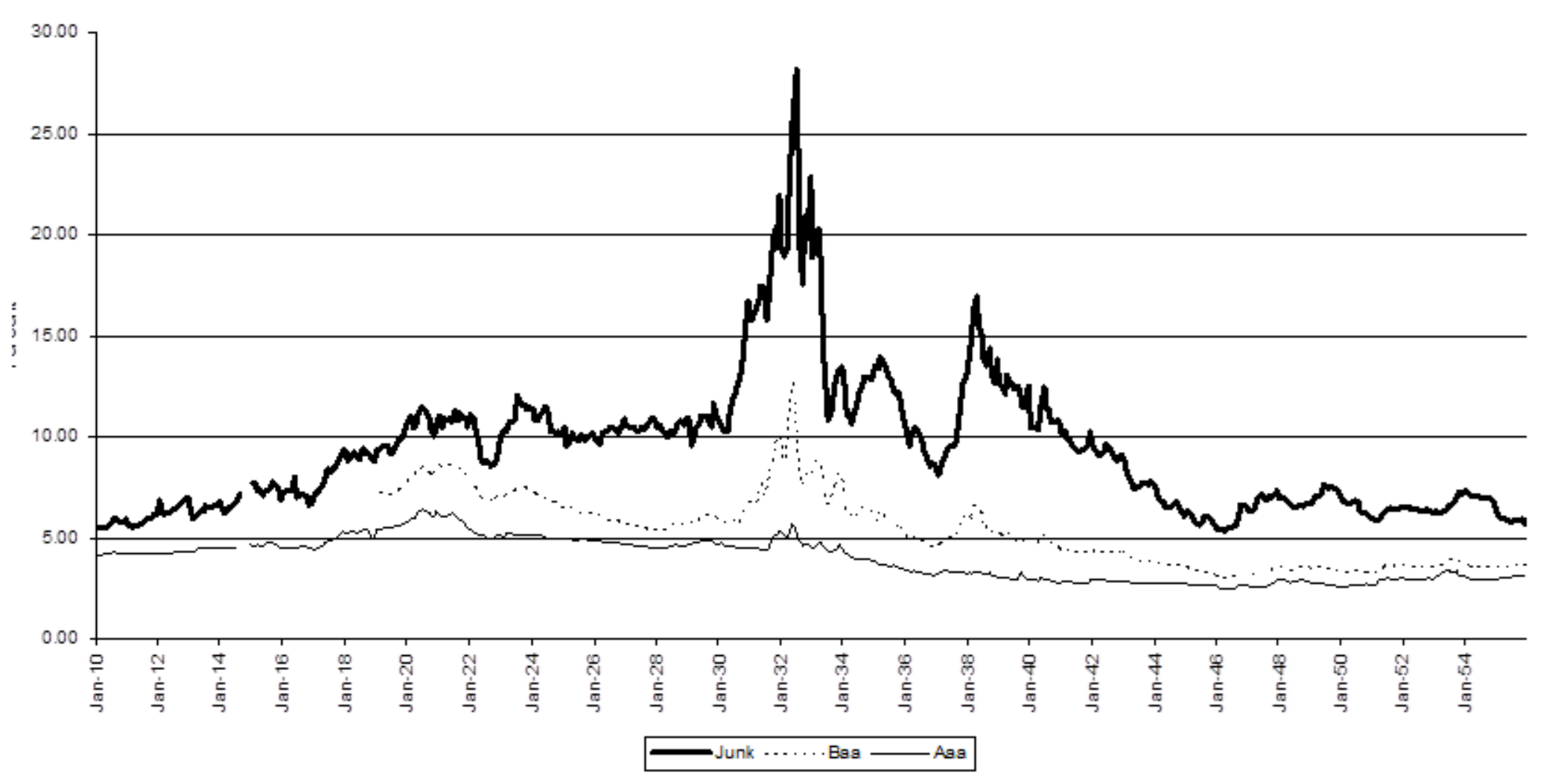

Figure 1. Yields of Corporate Bonds, 1910-55.

Sources. The Aaa and Baa rates are available from the Federal Reserve Bank of St. Louis at https://research.stlouisfed.org/fred2/. They were originally computed by Moody's. We extended the Aaa index back to 1910 using Macaulay's index of High Grade American Railroad Bond Yields, also available from the Federal Reserve Bank of St. Louis. No appropriate series was available for extending the Baa series. Junk Bond yields are from the appendix table. 


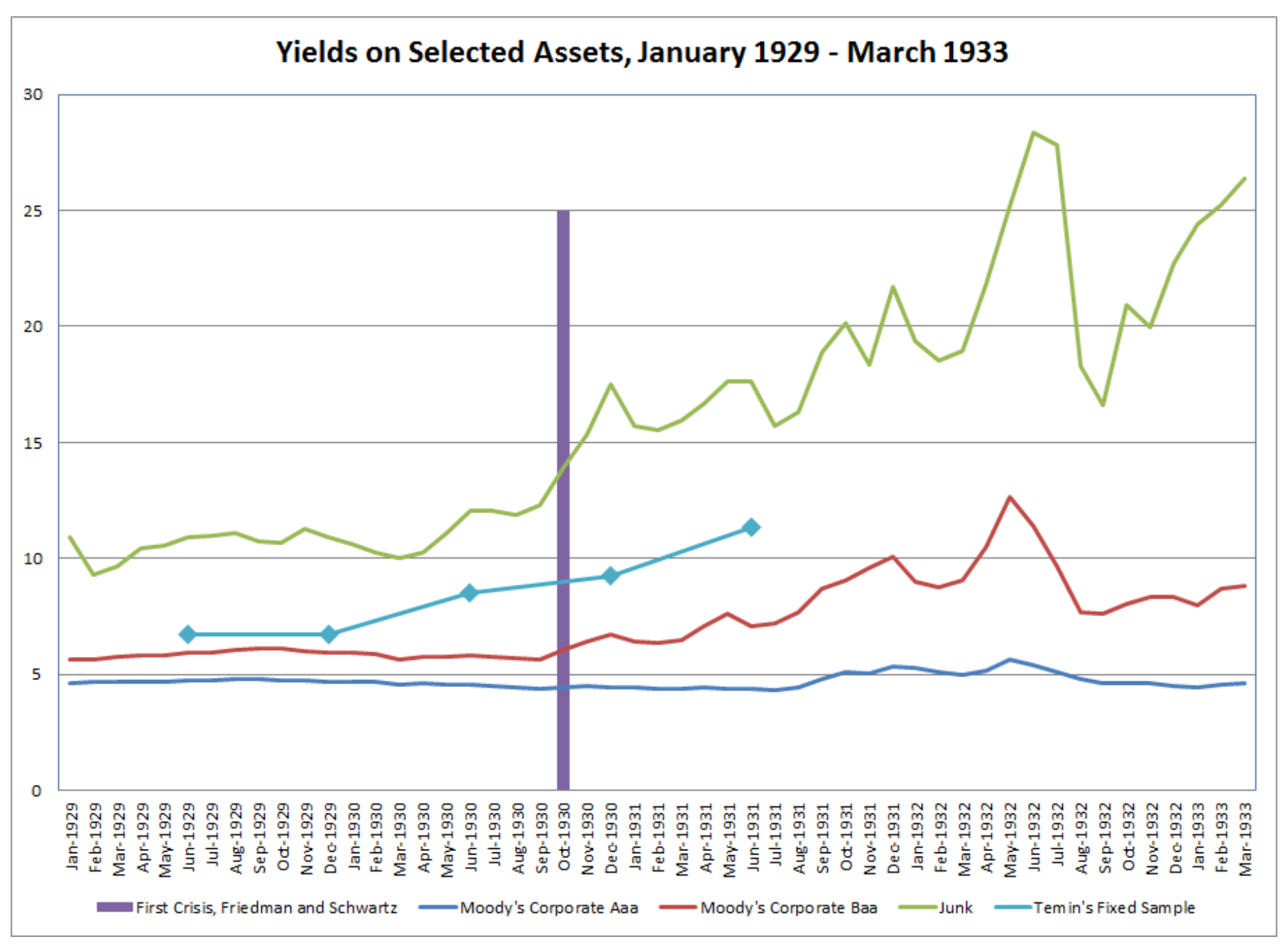

Figure 2: Yields of selected assets, January 1929 - March 1933.

Sources. The Aaa, Baa, and Junk rates, same as Figure 1. Temin's fixed sample, Temin $(1976,107)$. 


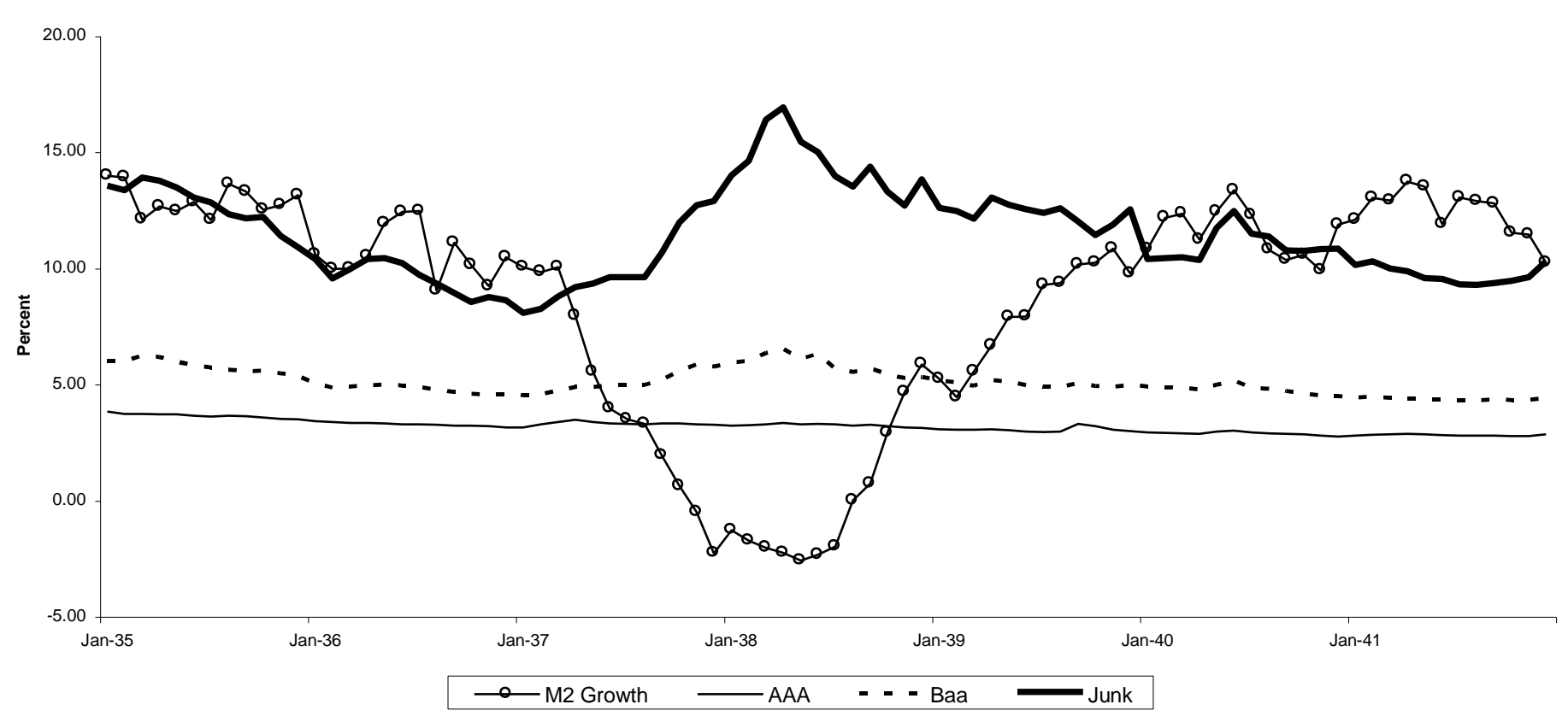

Figure 3. The Rate of Growth of Money and Selected Bond Yields, January 1935 - December 1941.

Sources. Money is M2 from Friedman and Schwartz (1970, 29-35). Bond yields, same as Figure 1. 


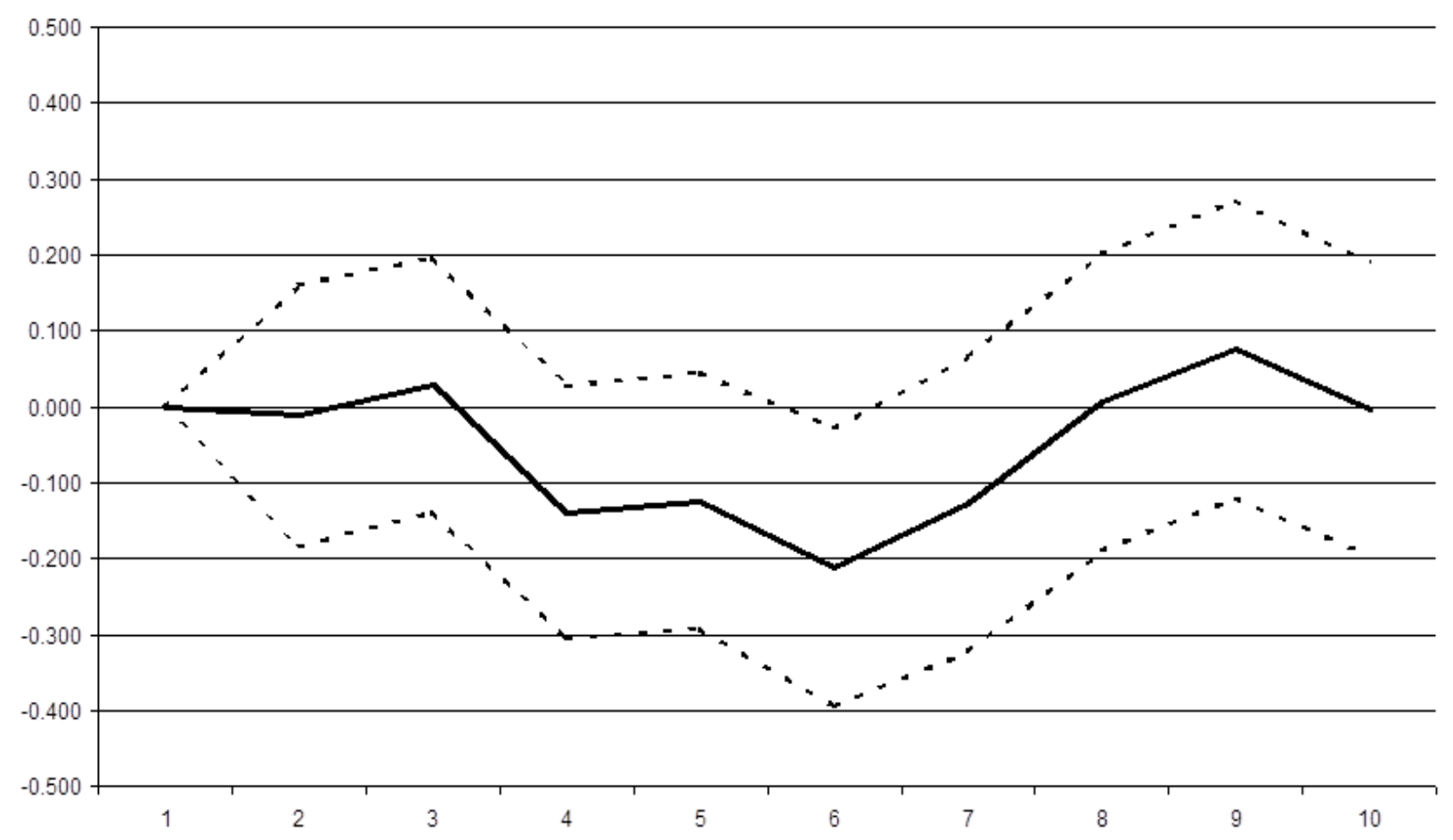

Figure 4. The Response of Junk Bond Yields to M2 Growth, 1934-1941 


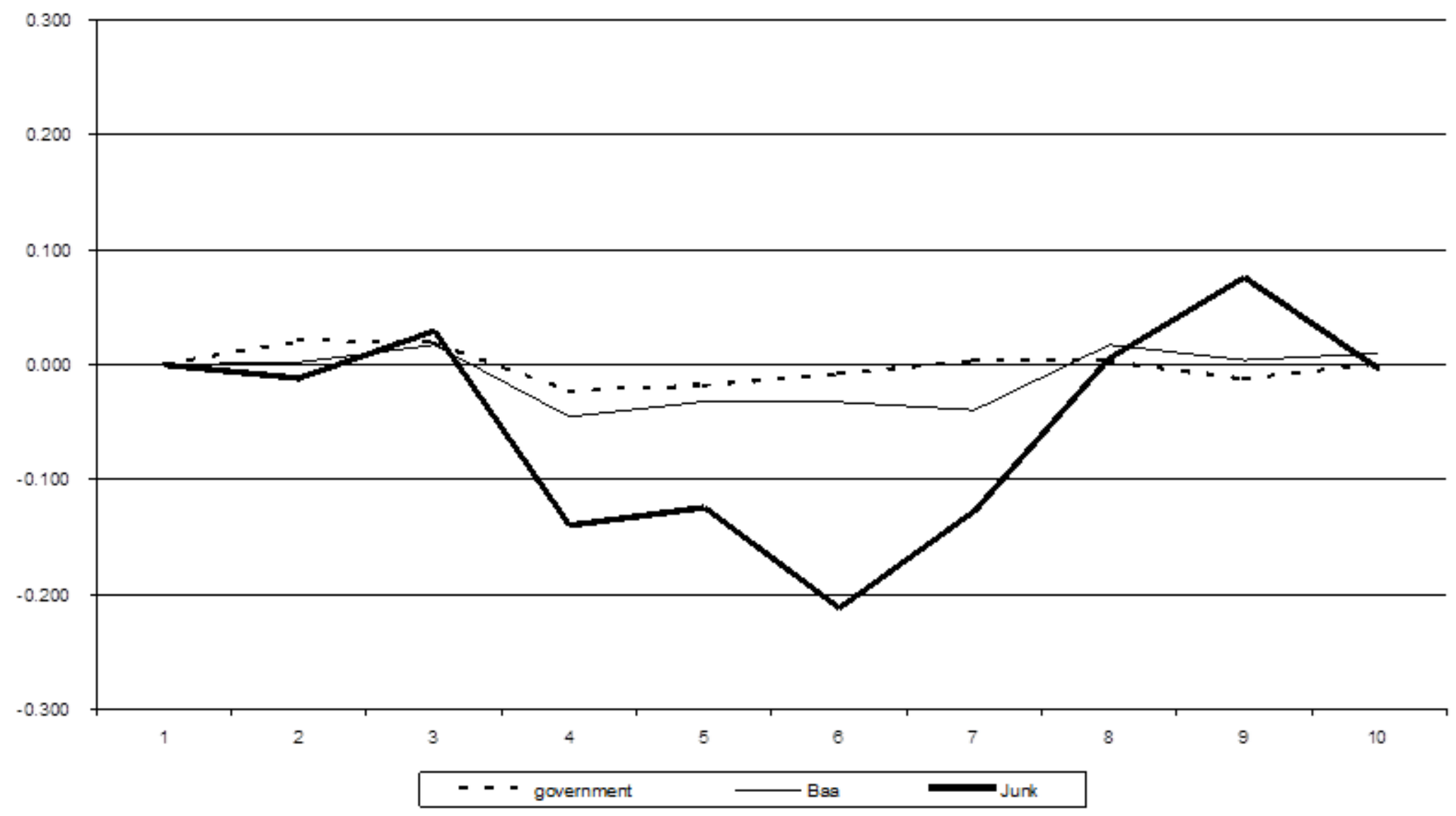

Figure 5. The Response of Three Corporate Bond Yields to M2 Growth, 1934-1941. 


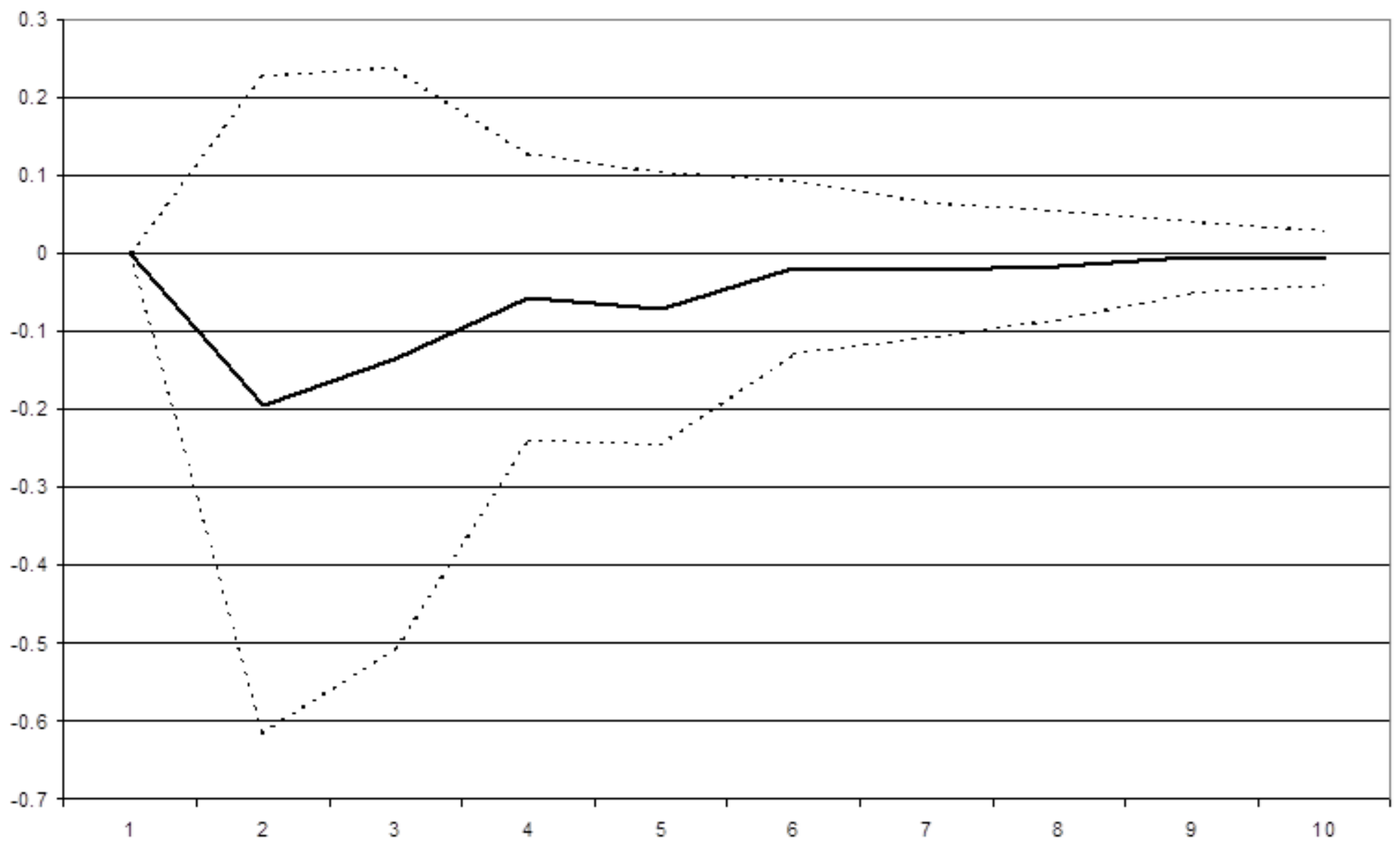

Figure 6. The Response of Junk Bond Yields to M2 Growth, Quarterly Data, 1934-1941. 


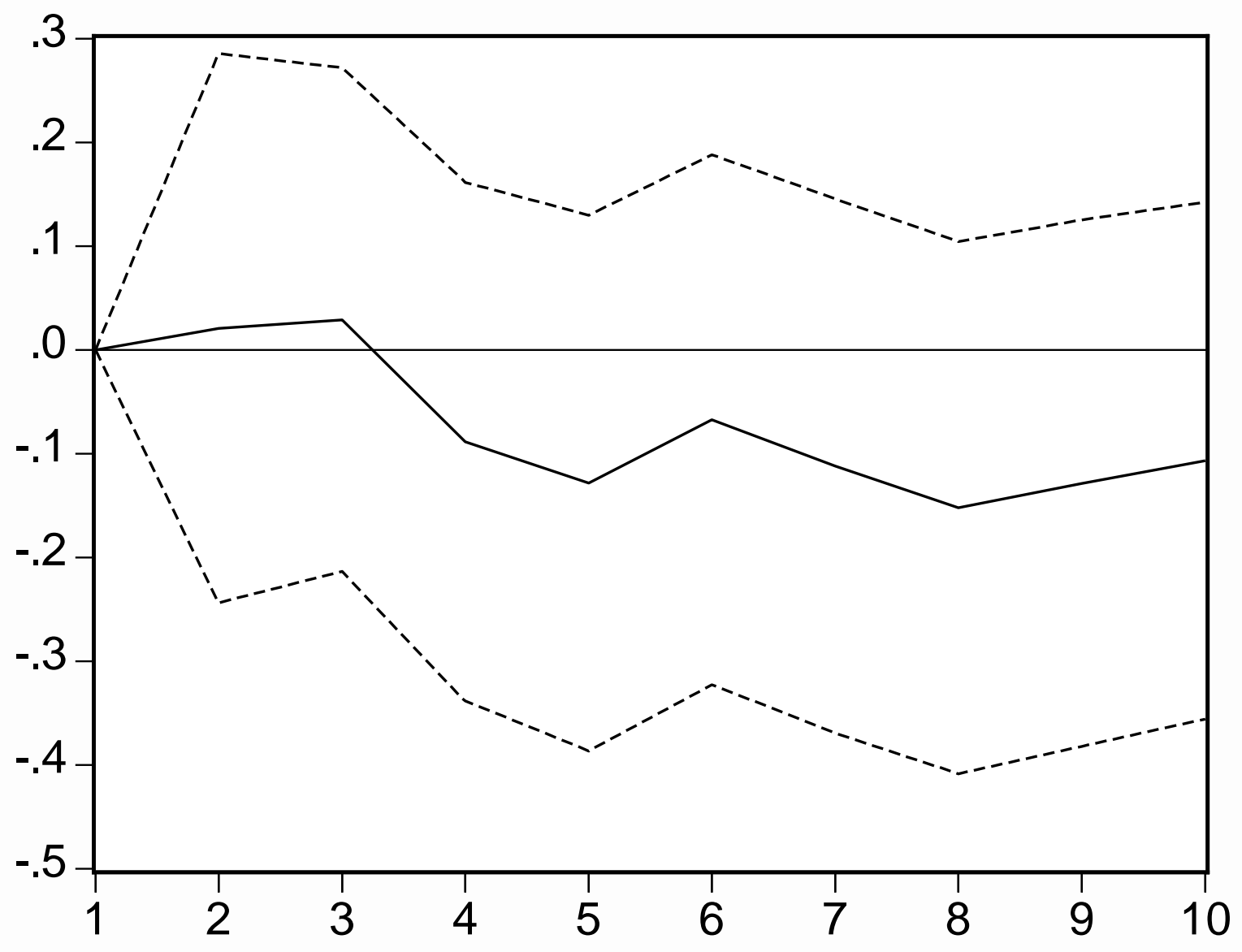

Figure 7. The Response of Junk Bond Yields to Changes in Money in Regressions that include Prices 


\begin{tabular}{|c|c|c|c|}
\hline Moody & Poor & Standard & Meaning \\
\hline Aaa & $A^{* *}$ & $A 1+$ & Highest Quality \\
\hline $\mathrm{Aa}$ & $A^{*}$ & A1 & High Quality \\
\hline A & A & A & Sound \\
\hline Baa & $\mathrm{B}^{\star *}$ & $\mathrm{~B} 1+$ & Good Quality \\
\hline $\mathrm{Ba}$ & $\mathrm{B}^{*}$ & B1 & Fair \\
\hline B & B & B & Speculative \\
\hline Caa & $C^{* *}$ & $\mathrm{C} 1+$ & Very Speculative \\
\hline $\mathrm{Ca}$ & $\mathrm{C}^{*}$ & C1 & Weak \\
\hline C & C & C & Gambles \\
\hline $\mathrm{D}$ & D & D & Default \\
\hline \multicolumn{4}{|c|}{$\begin{array}{l}\text { Notes: Junk bonds are often defined as those rated Ba or below. Our index is } \\
\text { confined to bonds rated B or below. Defaulted bonds are excluded. The verbal } \\
\text { descriptions are those used by Moody's during the period 1910-1955. Standard } \\
\text { and Poor were merged in 1941. A smaller firm, Fitch, also rated bonds. }\end{array}$} \\
\hline
\end{tabular}




\section{Table 2. The Response of Country Banks to the Great Contraction (Garlock's Select Sample of Rural Wisconsin Banks)}

\begin{tabular}{|l|c|c|c|c|}
\hline & High Grade & $\begin{array}{l}\text { Medium } \\
\text { Grade }\end{array}$ & Low Grade & Total \\
\hline Securities held in 1929 & 38 & 37 & 25 & 100 \\
\hline Securities sold 1929-32 & 25 & 17 & 10 & 52 \\
\hline $\begin{array}{l}\text { Proportion sold } \\
\text { (percent) }\end{array}$ & $66 \%$ & $46 \%$ & $40 \%$ & $52 \%$ \\
\hline $\begin{array}{l}\text { Securities remaining in } \\
\text { portfolio }\end{array}$ & 13 & 20 & 15 & 48 \\
\hline $\begin{array}{l}\text { Change in ratings of } \\
\text { securities held 1929-32 }\end{array}$ & 0 & -11 & +11 & 0 \\
\hline $\begin{array}{l}\text { Securities held from } \\
1929 \text { to 1932 at 1932 } \\
\text { ratings }\end{array}$ & 13 & 9 & 26 & 48 \\
\hline Securities acquired & 6 & 5 & 14 & 25 \\
\hline $\begin{array}{l}\text { Proportion of initial } \\
\text { holdings replaced } \\
\text { (percent) }\end{array}$ & $16 \%$ & $14 \%$ & $56 \%$ & $25 \%$ \\
\hline $\begin{array}{l}\text { Securities Held in 1932 } \\
\text { Note: Al secuilis ar }\end{array}$ & 19 & 14 & 40 & 73 \\
\hline
\end{tabular}

Note: All securities are valued at book value (acquisition price) and measured as a percentage of total security holdings in 1929. The definitions of the grades are as follows. High grade: U.S. Government Securities, Federal Land Bank Bonds, Aaa and Aa Corporates, and State and Municipal Bonds not in Default. Medium grade: A and Baa Corporates. Low grade: All others including defaulted and not rated.

Source: (Garlock 1941, 49-50). The figures were read from a chart. So there is a small margin of error, perhaps one percent, around the figures. 


\begin{tabular}{|c|c|c|c|c|}
\hline \multicolumn{5}{|l|}{ Table 3} \\
\hline & All Banks & \begin{tabular}{|l|} 
Banks that \\
Survived \\
without \\
establishing \\
a Depositor's \\
Trust
\end{tabular} & All Banks & All Banks \\
\hline Number of banks & 57 & 17 & 46 & 31 \\
\hline Year & 1929 & 1929 & 1932 & 1935 \\
\hline All U.S. Government Bonds & $23 \%$ & $22 \%$ & $17 \%$ & $40 \%$ \\
\hline Grade 1 (Aaa) & 7 & 9 & 4 & 2 \\
\hline Grade $2(\mathrm{Aa})$ & 5 & 8 & 6 & 6 \\
\hline Grade 3 and 4 (A-Baa) & 30 & 34 & 21 & 29 \\
\hline Grade 5 and $6(\mathrm{Ba}-\mathrm{B})$ & 15 & 10 & 21 & 13 \\
\hline $\begin{array}{l}\text { Grades } 7 \text { and other low-rated Bonds } \\
(\text { Caa-C) }\end{array}$ & 1 & 2 & 10 & 3 \\
\hline Nonrated, defaulted, and other & 19 & 15 & 22 & 8 \\
\hline Total & 100 & 100 & 100 & 100 \\
\hline \multicolumn{5}{|c|}{$\begin{array}{l}\text { Note: The state banking authority established the grades on the basis of ratings } \\
\text { provided by several services. The ratings in parentheses are my guess as to the } \\
\text { corresponding Moody's rating based on Garlock's description. }\end{array}$} \\
\hline
\end{tabular}




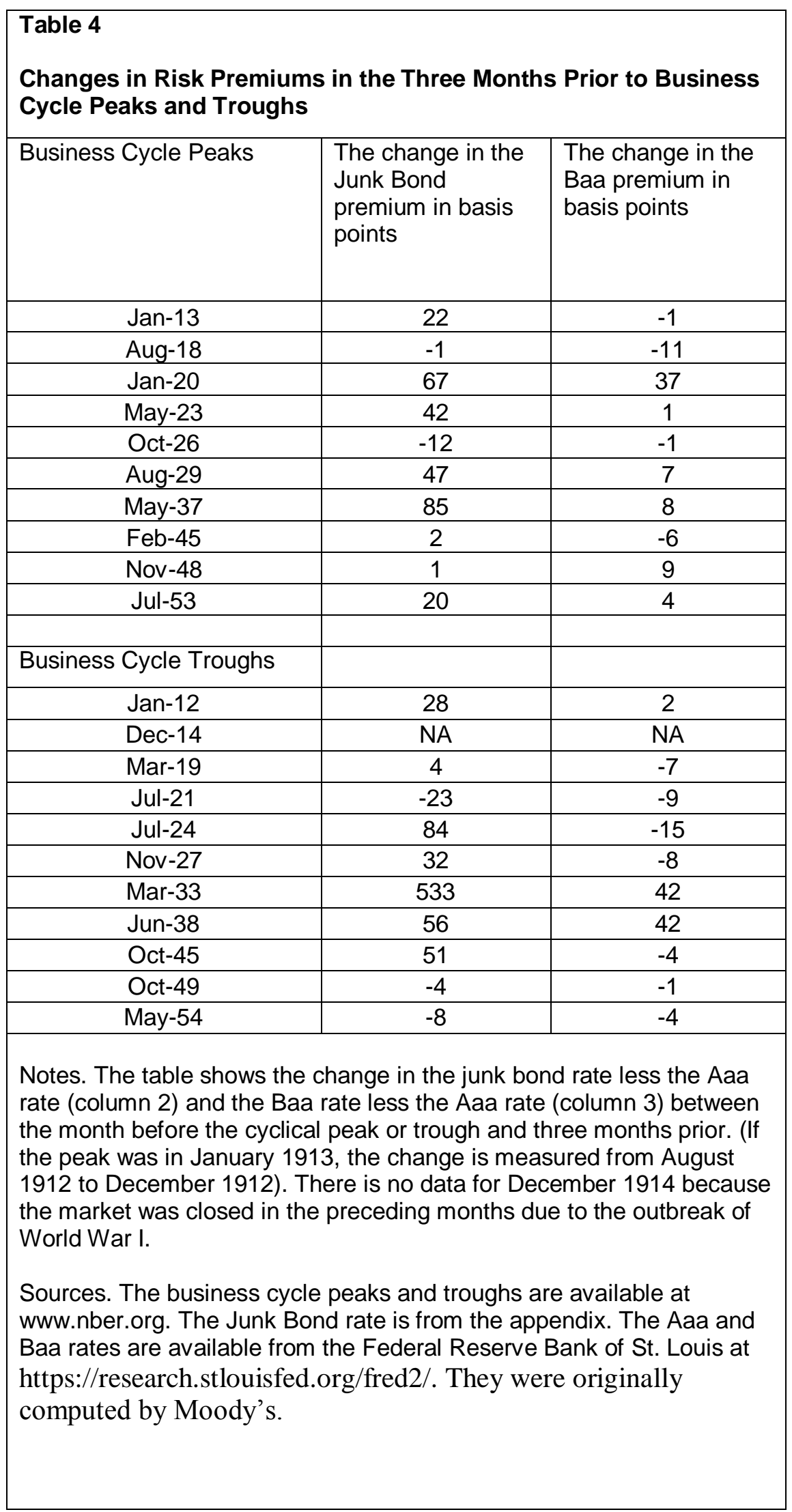




\section{Appendix: The Junk Bond Yields}

The table below shows our estimates of the junk bond yields for the period 1910-1955. The procedures used were those used by Macaulay (1938). The basic idea is to choose a group of bonds with similar characteristics and follow their yields over time. Although Macaulay's study was done some time ago, many of the problems he faced in computing nineteenth century yields also must be faced when computing an index of junk bonds.

Bonds with the following characteristics were chosen. (1) The bonds were rated B or lower by Moody's. (2) The bonds had to maintain their rating for 3 or more years. This avoids the possible volatility imparted by bonds that were rapidly moving up or down the rating scale. It does sometimes happen that the rating of a given junk bond is lowered quickly when bond is on the road to default. Our sample, in other words, includes "fallen angels," but not "falling angels." (3) The bonds had call provisions similar to modern junk bonds. The yields computed, however, were simple yields to maturity. No adjustments were made for call provisions. We did make sure, however, that all the bonds had similar call provisions. The sample is made up of a wide array of firms including railroads, utilities, and manufacturing firms. It varied in size. Before 1933 it averaged about 9, after 1933, about 18.

Prior to 1928 the price of the bond was the asking price from the General Quotation section of the Commercial and Financial Chronicle. From 1928 on, actual sales prices were used. Prior to 1919 only railroad bonds were used because the series usually used to show changes in interest rates on corporate bonds are Macaulay's series for railroad bonds. Macaulay's railroad bonds were not separated by risk class. For that reason we went back to Macaulay's data and created a new index of Aaa rated railroad bonds for the period 1910 to 1918, so that we 
would have a corporate Aaa series as similar in as many respects as possible, except risk, to our junk bond index.

Macaulay's system for chaining yields was used when it was necessary to replace securities in the sample. Replacement might be needed because the term to maturity of a security grew too short, because it went into default, or for some other reason. New bonds were added in January, and the average yield for each subsequent observation during the year was multiplied by the ratio of the average yield on the old sample of bonds in January to the yield on the new sample in January. This procedure raises questions for an index of junk bonds, since the sample of junk bonds is smaller than the samples for other classes of bonds, and yield differences between bonds being removed from the sample and bonds added might be substantial. For that reason we also computed the "average yield," which is simply the average for all bonds available at a particular date. In general, however, the average yield was quite close in level and movement to the chained (Macaulay-style) index. 


\begin{tabular}{|c|c|c|c|c|c|c|c|c|c|c|c|c|}
\hline \multicolumn{13}{|c|}{ Appendix Table. Junk Bond Yields, Monthly, 1910-1955 } \\
\hline Year & $\begin{array}{l}\text { 苟 } \\
\text { 売 }\end{array}$ & 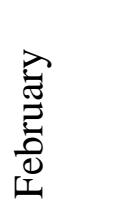 & 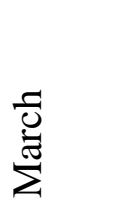 & 灾 & 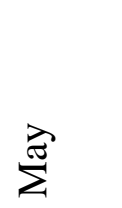 & 䍖 & 로 & 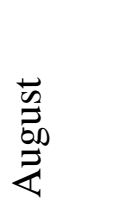 & 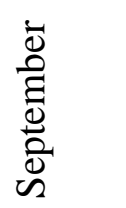 & $\begin{array}{l}\dot{\bar{U}} \\
\stackrel{0}{0} \\
\stackrel{0}{0}\end{array}$ & 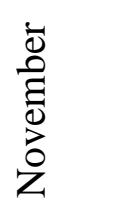 & 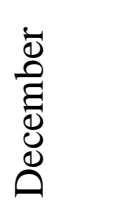 \\
\hline 1910 & 5.50 & 5.54 & 5.51 & 5.52 & 5.52 & 5.63 & 5.78 & 5.97 & 5.88 & 5.72 & 5.76 & 5.87 \\
\hline 1911 & 5.59 & 5.59 & 5.53 & 5.60 & 5.60 & 5.69 & 5.70 & 5.87 & 5.91 & 5.96 & 6.14 & 6.15 \\
\hline 1912 & 6.79 & 6.25 & 6.10 & 6.23 & 6.23 & 6.39 & 6.39 & 6.51 & 6.69 & 6.72 & 6.91 & 6.95 \\
\hline 1913 & 6.53 & 5.87 & 6.06 & 6.13 & 6.26 & 6.27 & 6.59 & 6.45 & 6.41 & 6.52 & 6.56 & 6.71 \\
\hline 1914 & 6.55 & 6.19 & 6.29 & 6.42 & 6.54 & 6.65 & 6.77 & 7.17 & NA & NA & NA & NA \\
\hline 1915 & 7.70 & 7.70 & 7.28 & 7.33 & 7.07 & 7.26 & 7.30 & 7.52 & 7.73 & 7.56 & 7.28 & 6.79 \\
\hline 1916 & 7.22 & 7.30 & 7.26 & 7.26 & 7.99 & 7.01 & 7.06 & 7.11 & 7.07 & 6.99 & 6.62 & 6.66 \\
\hline 1917 & 7.19 & 7.14 & 7.34 & 7.50 & 7.86 & 8.35 & 8.24 & 8.37 & 8.45 & 8.83 & 9.01 & 9.32 \\
\hline 1918 & 9.26 & 8.76 & 8.93 & 9.26 & 9.15 & 8.87 & 9.29 & 9.42 & 9.14 & 9.15 & 8.92 & 8.79 \\
\hline 1919 & 9.34 & 9.36 & 9.44 & 9.52 & 9.57 & 9.16 & 9.18 & 9.35 & 9.76 & 9.87 & 9.97 & 10.57 \\
\hline 1920 & 10.66 & 11.05 & 10.35 & 10.46 & 11.19 & 11.44 & 11.38 & 11.17 & 10.88 & 10.33 & 10.01 & 10.52 \\
\hline 1921 & 10.98 & 10.38 & 10.84 & 10.79 & 10.91 & 10.72 & 11.28 & 10.78 & 11.15 & 10.89 & 10.95 & 10.50 \\
\hline 1922 & 11.05 & 10.93 & 10.36 & 9.78 & 8.76 & 8.65 & 8.80 & 8.68 & 8.53 & 8.58 & 8.86 & 9.55 \\
\hline 1923 & 10.12 & 10.28 & 10.25 & 10.71 & 10.71 & 10.79 & 12.00 & 11.75 & 11.52 & 11.57 & 11.33 & 11.41 \\
\hline 1924 & 11.35 & 10.78 & 10.75 & 11.11 & 11.22 & 11.49 & 11.02 & 10.21 & 10.20 & 10.19 & 10.25 & 10.08 \\
\hline
\end{tabular}




\begin{tabular}{|c|c|c|c|c|c|c|c|c|c|c|c|c|}
\hline 1925 & 10.39 & 9.56 & 9.57 & 10.14 & 9.96 & 9.84 & 9.79 & 10.04 & 9.75 & 9.92 & 9.98 & 10.14 \\
\hline 1926 & 9.91 & 9.72 & 9.64 & 10.15 & 10.20 & 10.31 & 10.44 & 10.41 & 10.28 & 10.19 & 10.38 & 10.89 \\
\hline 1927 & 10.54 & 10.47 & 10.45 & 10.47 & 10.23 & 10.28 & 10.47 & 10.33 & 10.50 & 10.70 & 10.93 & 10.85 \\
\hline 1928 & 10.44 & 10.56 & 10.38 & 10.08 & 9.94 & 10.27 & 10.11 & 10.33 & 10.59 & 10.80 & 10.56 & 10.85 \\
\hline 1929 & 10.94 & 9.51 & 9.81 & 10.43 & 10.58 & 11.00 & 10.98 & 11.05 & 10.74 & 10.50 & 11.66 & 10.94 \\
\hline 1930 & 10.61 & 10.47 & 10.27 & 10.27 & 11.04 & 11.85 & 12.07 & 12.45 & 12.96 & 13.94 & 15.17 & 16.64 \\
\hline 1931 & 15.73 & 15.87 & 16.26 & 16.69 & 17.46 & 17.34 & 15.71 & 16.70 & 18.94 & 20.13 & 19.29 & 21.92 \\
\hline 1932 & 19.35 & 18.89 & 19.29 & 21.91 & 25.25 & 27.09 & 28.15 & 19.27 & 17.50 & 20.82 & 19.80 & 22.81 \\
\hline 1933 & 18.81 & 19.44 & 20.24 & 19.10 & 14.17 & 11.93 & 10.81 & 11.12 & 12.38 & 12.90 & 13.28 & 13.37 \\
\hline 1934 & 13.04 & 11.03 & 11.14 & 10.65 & 11.22 & 11.40 & 12.19 & 12.49 & 12.96 & 12.84 & 12.86 & 12.76 \\
\hline 1935 & 13.50 & 13.30 & 13.86 & 13.72 & 13.42 & 13.00 & 12.78 & 12.27 & 12.09 & 12.17 & 11.35 & 10.84 \\
\hline 1936 & 10.33 & 9.51 & 9.91 & 10.35 & 10.38 & 10.18 & 9.66 & 9.30 & 8.89 & 8.49 & 8.71 & 8.57 \\
\hline 1937 & 8.03 & 8.20 & 8.74 & 9.13 & 9.28 & 9.57 & 9.57 & 9.57 & 10.62 & 11.92 & 12.66 & 12.84 \\
\hline 1938 & 13.95 & 14.57 & 16.36 & 16.88 & 15.40 & 14.95 & 13.91 & 13.46 & 14.33 & 13.26 & 12.65 & 13.77 \\
\hline 1939 & 12.55 & 12.41 & 12.07 & 12.99 & 12.68 & 12.49 & 12.34 & 12.52 & 11.96 & 11.37 & 11.83 & 12.49 \\
\hline 1940 & 10.35 & 10.39 & 10.43 & 10.31 & 11.69 & 12.42 & 11.43 & 11.31 & 10.71 & 10.70 & 10.77 & 10.79 \\
\hline 1941 & 10.08 & 10.24 & 9.95 & 9.82 & 9.54 & 9.49 & 9.25 & 9.23 & 9.31 & 9.41 & 9.57 & 10.23 \\
\hline 1942 & 9.48 & 9.20 & 9.05 & 9.08 & 9.22 & 9.63 & 9.47 & 9.25 & 8.99 & 8.80 & 8.97 & 9.07 \\
\hline 1943 & 8.73 & 8.39 & 7.91 & 7.60 & 7.37 & 7.43 & 7.50 & 7.65 & 7.64 & 7.58 & 7.75 & 7.68 \\
\hline
\end{tabular}




\begin{tabular}{|c|c|c|c|c|c|c|c|c|c|c|c|c|}
\hline 1944 & 7.48 & 7.09 & 6.85 & 6.77 & 6.55 & 6.44 & 6.52 & 6.62 & 6.71 & 6.48 & 6.32 & 6.04 \\
\hline 1945 & 6.30 & 6.22 & 6.05 & 5.84 & 5.70 & 5.60 & 5.67 & 6.06 & 6.08 & 5.96 & 5.71 & 5.53 \\
\hline 1946 & 5.42 & 5.31 & 5.32 & 5.31 & 5.44 & 5.42 & 5.48 & 5.54 & 6.12 & 6.59 & 6.57 & 6.42 \\
\hline 1947 & 6.27 & 6.27 & 6.45 & 6.71 & 7.06 & 7.15 & 6.88 & 6.84 & 7.05 & 6.97 & 7.12 & 7.27 \\
\hline 1948 & 6.88 & 6.92 & 6.89 & 6.76 & 6.55 & 6.47 & 6.46 & 6.56 & 6.56 & 6.51 & 6.64 & 6.66 \\
\hline 1949 & 6.64 & 6.89 & 7.05 & 7.09 & 7.18 & 7.57 & 7.49 & 7.39 & 7.48 & 7.36 & 7.37 & 7.12 \\
\hline 1950 & 6.72 & 6.71 & 6.70 & 6.69 & 6.74 & 6.85 & 6.73 & 6.31 & 6.17 & 6.17 & 6.11 & 5.96 \\
\hline 1951 & 5.85 & 5.79 & 5.91 & 6.05 & 6.18 & 6.36 & 6.45 & 6.40 & 6.34 & 6.37 & 6.46 & 6.45 \\
\hline 1952 & 6.42 & 6.47 & 6.45 & 6.39 & 6.39 & 6.33 & 6.28 & 6.26 & 6.32 & 6.37 & 6.29 & 6.17 \\
\hline 1953 & 6.27 & 6.19 & 6.20 & 6.29 & 6.38 & 6.62 & 6.63 & 6.76 & 7.06 & 7.18 & 7.17 & 7.21 \\
\hline 1954 & 7.30 & 7.11 & 7.08 & 7.06 & 7.02 & 6.96 & 6.89 & 6.87 & 6.90 & 6.88 & 6.71 & 6.48 \\
\hline 1955 & 6.03 & 5.98 & 5.95 & 5.88 & 5.83 & 5.75 & 5.78 & 5.83 & 5.83 & 5.86 & 5.70 & 5.83 \\
\hline
\end{tabular}

Source: See the text of the Appendix. The market was closed from August to December 1914 because of the start of World War I. 